\title{
The Application of Active Biomonitoring with the Use of Mosses to Identify Polycyclic Aromatic Hydrocarbons in an Atmospheric Aerosol
}

\author{
Paweł Świsłowski ${ }^{1, *(1)}$, Pavel Hrabák ${ }^{2}\left(\mathbb{D}\right.$, Stanisław Wacławek ${ }^{2}{ }^{(0)}$, Klára Liskova ${ }^{2}$, Vojtěch Antos ${ }^{2}$, \\ Małgorzata Rajfur ${ }^{3}$ (i) and Maria Ząbkowska-Wacławek ${ }^{4}$ \\ 1 Institute of Biology, University of Opole, Oleska 22 St., 45-022 Opole, Poland \\ 2 Institute for Nanomaterials, Advanced Technologies and Innovation, Technical University of Liberec, \\ Studentská St. 1402/2, 46117 Liberec 1, Czech Republic; pavel.hrabak@tul.cz (P.H.); \\ stanislaw.waclawek@tul.cz (S.W.); klara.liskova1@tul.cz (K.L.); vojtech.antos@tul.cz (V.A.) \\ 3 Institute of Environmental Engineering and Biotechnology, University of Opole, Kominka 6a St., \\ 45-032 Opole, Poland; rajfur@uni.opole.pl \\ 4 Society of Ecological Chemistry and Engineering, Zawiszaków St. 3/103, 45-288 Opole, Poland; \\ maria.waclawek@o2.pl \\ * Correspondence: pawel.swislowski@uni.opole.pl
}

Citation: Świsłowski, P.; Hrabák, P.; Wacławek, S.; Liskova, K.; Antos, V.; Rajfur, M.; Zabkowska-Wacławek, M. The Application of Active Biomonitoring with the Use of Mosses to Identify Polycyclic Aromatic Hydrocarbons in an Atmospheric Aerosol. Molecules 2021, 26, 7258. https://doi.org/10.3390/ molecules 26237258

Academic Editor: Cristian Gomez-Canela

Received: 8 October 2021

Accepted: 29 November 2021

Published: 30 November 2021

Publisher's Note: MDPI stays neutral with regard to jurisdictional claims in published maps and institutional affiliations.

Copyright: (c) 2021 by the authors. Licensee MDPI, Basel, Switzerland. This article is an open access article distributed under the terms and conditions of the Creative Commons Attribution (CC BY) license (https:/ / creativecommons.org/licenses/by/ $4.0 /)$.

\begin{abstract}
The use of biological indicators of environmental quality is an alternative method of monitoring ecosystem pollution. Various groups of contaminants, including organic ones, can be measured in environmental samples. Polycyclic aromatic hydrocarbons (PAHs) have not yet been determined by the moss bag technique. This technique uses several moss species simultaneously in urban areas to select the best biomonitoring of these compounds, which are dangerous to humans and the environment. In this research, a gas chromatography coupled with mass spectrometry was used for the determination of selected PAHs in three species of mosses: Pleurozium schreberi, Sphagnum fallax and Dicranum polysetum (active biomonitoring) and for comparison using an air filter reference method for atmospheric aerosol monitoring. The chlorophyll fluorescence of photosystem II (PSII) was also measured to assess changes in moss viability during the study. As a result of the study, the selective accumulation of selected PAHs by mosses was found, with Pleurozium schreberi being the best bioindicator -9 out of 13 PAHs compounds were determined in this species. The photosynthetic yield of photosystem (II) decreased by $81 \%$ during the exposure time. The relationship between PAHs concentrations in mosses and the total suspended particles (TSP) on the filter indicated the possibility of using this bioindicator to trace PAHs in urban areas and to apply the moss bag technique as a method supporting classical instrumental air monitoring.
\end{abstract}

Keywords: polycyclic aromatic hydrocarbons; bioindicator; moss bag technique

\section{Introduction}

Environmental monitoring, including the assessment of exposure to polycyclic aromatic hydrocarbons (PAHs) is based on internal and external exposure [1]. In the first case, we deal with metabolites of PAHs in human body samples [2,3]. The second case is the exposure of people to (working) conditions, where the exposure to PAHs occurs [4,5], which may take the form of both short-term and long-term monitoring [6,7]. PAHs are compounds that have proven mutagenic effects, but they also negatively affect endocrine, reproductive and developmental processes. However, the most serious health effect of human exposure to PAHs is the proven impact of nine compounds from this group on the initiation of the cancer process [8]. These compounds are: anthracene, benz[a]anthracene, benzo[a]pyrene, chrysene, benzo[b]fluoranthene, benzo[k]fluoranthene, dibenz[ $(\mathrm{a}, \mathrm{h}] \mathrm{anthracene}$, benzo[ghi]perylene and indeno[1,2,3-cd]pyrene. There are three routes through which PAHs enter the human body: oral, inhalation and intracutaneous, 
with the intracutaneous route being considered the least relevant for environmental exposure [9]. Additionally, PAHs concentration can be measured in environmental samples to indicate local long-term atmospheric deposition, identify various PAH sources by fingerprints of individual $\mathrm{PAH}$ percentage occurance on the total $\mathrm{PAH}$, or to understand environmental transformation. For this purpose, oxy-, hydroxy- and nitro-PAH derivatives are significant [10].

The natural properties of plants make this group of organisms quite widely used in biological monitoring of PAHs [11]; however, there is a lack of monitoring reports on PAH concentrations in animals in aquatic ecosystems $[12,13]$ or spider webs $[14,15]$. The use of environmental samples is, therefore, quite common in the monitoring and determination of PAHs environmental fluxes.

The use of mosses as biomonitors of organic pollutants was previously reviewed several times [16-18]. This research has a long history, has existed for several decades $[19,20]$ and primarily only concerns the deposition of PAH in different moss species. These studies focus on the use of herbarium specimens as indicators of historical changes and trends in PAH contamination [21,22]. They are used as tools in national and international biomonitoring projects [23,24], and in comparative studies with other bioindicators [25]. One species used in this kind of study, Pleurozium schreberi [26,27], is also applied to national surveys $[28,29]$.

Active biomonitoring has an equally long history of PAH monitoring using mosses [30-32]. However, the moss bag technique is characterised by the continuous optimisation of the research methodology [33], also used for the determination of PAHs [34-37]. Similar to passive biomonitoring, studies on PAH determination using the moss bag technique explore the possibility of using different bioindicators simultaneously [38-41] or long-term studies with an indication of seasonal variations [42]. However, according to the definition of biomonitoring, the study should take into account the physiological state of the bioindicator and consider its vital functions [43]. Meanwhile, active biomonitoring studies using mosses often use devitalized material $[38,39]$. However, atmospheric concentrations of PAH can be underestimated when dead mosses are used in the moss bag technique [44], and the relevance of using live mosses in research has been demonstrated [45].

PAH pollution in Poland is a large problem in urban agglomerations [46], and their measurement by mosses takes place mainly as passive biomonitoring [47]. There is little work in the literature that integrates active biomonitoring to complement classical instrumental monitoring [48].

The aim of our study was to apply the moss bag technique using three moss species: Pleurozium schreberi, Sphagnum fallax and Dicranum polysetum, to assess the PAH air pollution of an urban area during the winter period and to demonstrate the selective accumulation properties of these moss species towards PAHs. The study also aimed to demonstrate the applicability of active biomonitoring as a supporting method for the instrumental monitoring of PAHs.

\section{Results}

Figure 1 shows the concentrations of selected PAHs accumulated by three moss species during a 12-week exposure. 


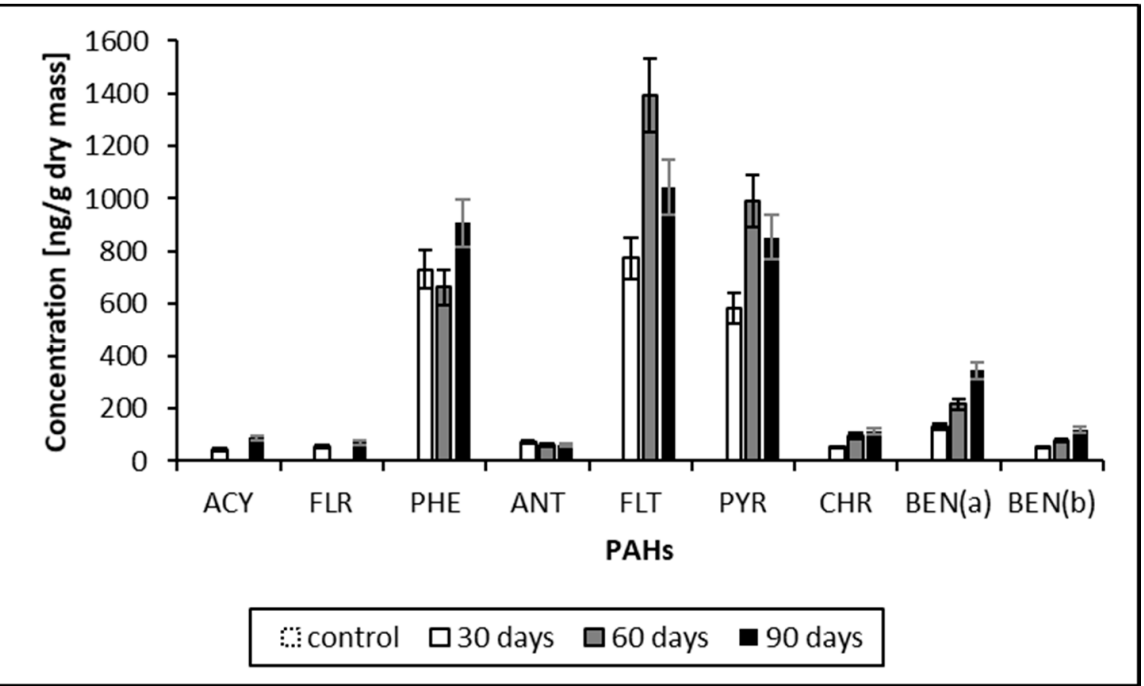

(a)

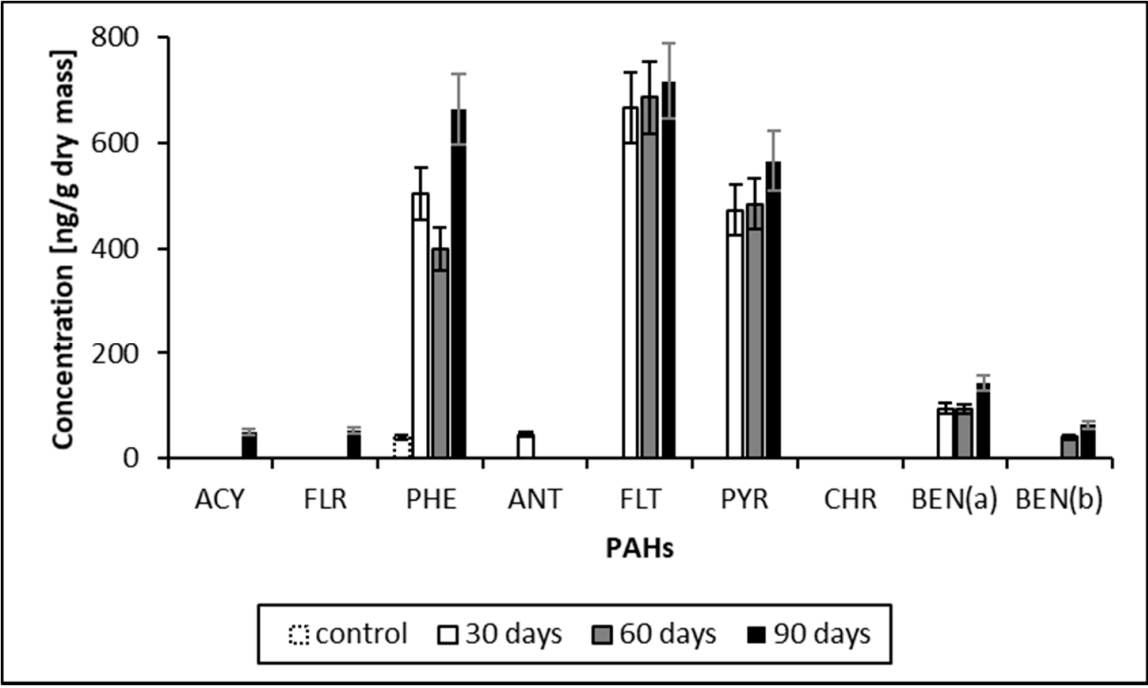

(b)

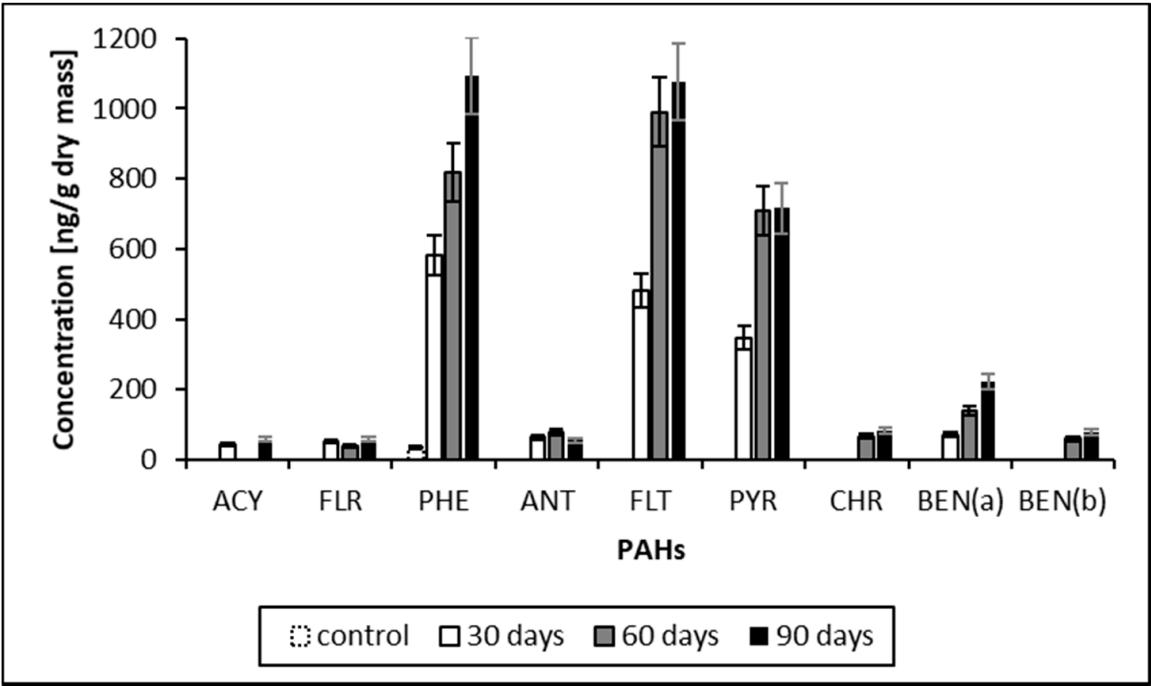

(c)

Figure 1. Increments of PAH concentrations accumulated in mosses: (a) Pleurozium schreberi (Pl); (b) Sphagnum fallax (Sp); (c) Dicranum polysetum (Dp). The colors of bars represent growths after the 
first (white), second (grey) and third (black) months of exposure. The white bar outlined with a dashed line represents the concentration of the control (moss sample that has not been exposed). The absence of a bar indicates that the concentration in the control sample was $<10.0 \mathrm{ng} / \mathrm{g}$ limit of detection (LOD). PAH concentration increments, i.e., the concentration measured in the post-exposure sample $(\mathrm{Cm})$ subtracted from the concentration in the control sample $(\mathrm{Cc})$ : $\mathrm{Cm}-\mathrm{Cc}$. Abbreviations for PAHs: Acenaphthylene (ACY); Fluorene (FLR); Phenanthrene (PHE); Anthracene (ANT); Fluoranthene (FLT); Pyrene (PYR); Chrysene (CHR); Benzo(a)anthracene (BEN(a)); Ben-zo(b)fluoranthene (BEN(b)).

The concentrations of PAHs accumulated by mosses, shown in Figure 1, indicate a monotonic accumulation with the duration of the exposure period for most compounds. For all three species, this is eight compounds (after the second and third month of exposure); for $\mathrm{Pl}$ and $\mathrm{Dp}$, it is also CHR. Four PAH compounds have the highest concentrations irrespective of exposure duration; these are PHE, FLT, PYR and BEN(a). Based on the statistical significance between PAH concentrations accumulated in the three moss species calculated by the Wilcoxon test, p was: Pl and Sp < 0.001 (0.0003), Pl and Dp $<0.05$ (0.011) and $\mathrm{Sp}$ and $\mathrm{Dp}<0.05$ (0.022). Therefore, the species can be ranked with respect to the value of PAH concentrations and irrespective of time according to the co-efficient: $\mathrm{Pl}>\mathrm{Dp}>\mathrm{Sp}$.

The measured value of actual photochemical efficiency (yield) indicates a decrease in value during moss exposure in winter. The mean initial value in the control samples was 0.696 , and after three months, it was 0.133 . The decrease in photosynthetic activity by $81.0 \%$ after 12 weeks of exposure was caused by environmental stress due to changeable weather conditions and air pollution (due to the heating season), including PAHs and heavy metals (work in progress). In the next step, the concentrations of PAHs deposited in TSP and accumulated on the filter were analyzed by instrumental monitoring (Table 1)

Table 1. Mean concentrations of PAHs accumulated on air filter.

\begin{tabular}{cc}
\hline Acronym & C $_{\text {PAH }}[\mu \mathbf{g} / \mathbf{g}]$ \\
\hline PHE & 28.5 \\
ANT & 6.28 \\
FLT & 143 \\
PYR & 137 \\
CHR & 123 \\
BEN(a) & 138 \\
BEN(b) & 144 \\
BEN(k) & 41.6 \\
BEN(a)PYR & 91.3 \\
IND & 73.9 \\
DIB & 15.0 \\
\hline
\end{tabular}

PAH abbreviations: Benzo(k)fluoranthene (BEN(k)); Benzo(a)pyrene (BEN(a)PYR); In-deno(1.2.3)-cd_pyrene (IND); Dibenzo(a.h)anthracene (DIB).

The values presented in Table 1 indicate high daily increments of extracted PAHs on the filter. In relation to mosses, four additional compounds were also determined in the TSP on the filter: BEN(k), BEN(a)PYR, IND and DIB. The values are disproportionately high compared to the concentrations accumulated by mosses. In the TSP, 11 PAH compounds were determined on the filter. The common compounds determined in all moss species and on the filter were: PHE, ANT, FLT, PYR and BEN(a). Figure 2 shows the correlation of the concentrations of the compounds mentioned above accumulated by the mosses (Pl, Sp, $\mathrm{Dp}$ ) in relation to the same PAH compounds deposited on the filter (TSP).

Cluster analysis between PAHs concentration on filter and mosses reveals clusters with varying linkage distance. The results obtained by mosses are significantly different from the ones obtained by classical monitoring. The results indicate a weak relationship between the concentrations of PAHs in the moss bag active biomonitoring technique and classical instrumental monitoring, which shows the differing performances of the two techniques. 


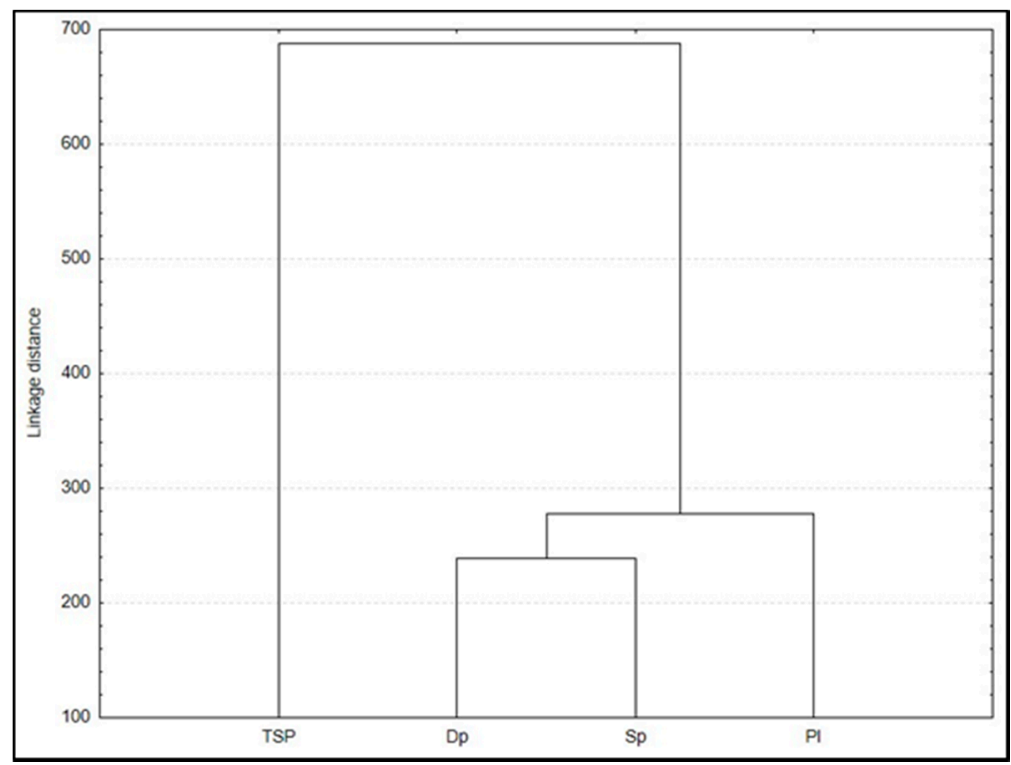

Figure 2. Cluster analysis of PAHs concentrations in three moss species and in TSP on the filter (Single linkage, Euclidean distance).

\section{Discussion}

To date, there has been little work in active biomonitoring where the species used were also involved in the biological monitoring of post-airborne PAH contamination. Two papers concern the application of the moss bag technique for the species Pleurozium schreberi [31,49]. In the first paper, where PAH concentrations in mosses are compared to PAH contamination in snow samples, the determined compounds differ from those determined in our study. P. schreberi in the presented study also accumulated na-phtalene, acenapthene, benzo(a)pyrene, indenopyrene, dibenzo(ah)anthracene and ben-zo(ghi)perylene. However, in our study, the concentrations determined for common PAH compounds were higher after the same exposure time. The determination of additional PAHs may have been influenced by the location of the study-a motorway, and thus the impact of car traffic, exhaust emissions. In addition, the authors found an advantage of using the moss bag technique in PAH deposition over snow sampling for this type of study [31]. In the second case, where the same species (Ps) were also exposed, moss transplantation using the moss bag technique lasted only one week in the cemeteries during the All Saints' Day period. The study indicated that the burning of candles caused the emission of selected PAHs [49]: benzo[b]fluoranthene and benzo[k]fluoranthene, dibenzo[a,h]anthracene, naphthalene, pyrene, indeno[1,2,3-cd]pyrene and ben-zo[g,h,i]perylene. Both the concentrations obtained and the PAH compounds determined were influenced by the samples' times and places of exposure. Two further national studies also investigated the use of $P$. schreberi in PAH monitoring, but this time by the box moss transplantation technique. The analyses showed that the determined PAH compounds were similar to those determined in this study. As in previous studies, the concentrations were very low, despite the longer exposure time (6 months) [50]. The low concentrations obtained may be due to the exposure method used [50,51].

Due to the lack of studies in the literature analyzing the PAH content of the other two species used by us (Sp and Dp), we decided to present selected literature data in tabular form on the application of the moss bag technique using other moss species for PAH determination (Table 2). 
Table 2. Comparison of PAH concentrations accumulated by other moss species in comparison to this work.

\begin{tabular}{|c|c|c|c|c|c|c|c|c|c|c|c|}
\hline \multicolumn{12}{|c|}{ Mean of PAHs Concentration [ng/g] } \\
\hline Species & ACY & FLR & PHE & ANT & FLT & PYR & CHR & BEN(a) & BEN(b) & $\begin{array}{c}\text { Time of } \\
\text { Exposure }\end{array}$ & References * \\
\hline P. schreberi & 88.0 & 69.5 & 908 & 60.2 & 1043 & 853 & 111 & 343 & 116 & 12 weeks & This study \\
\hline S. fallax & 49.4 & 53.1 & 665 & $<10.0$ & 717 & 566 & $<10.0$ & 144 & 62.9 & 12 weeks & This study \\
\hline D. polysetum & 57.1 & 57.1 & 1093 & 53.0 & 1077 & 718 & 81.6 & 220 & 77.5 & 12 weeks & This study \\
\hline H. splendens & 23 & 24 & 413 & 59 & 708 & 835 & 313 & 188 & 290 & 4 weeks & [52] \\
\hline H. cupressiforme & n.d. & n.d. & 84 & 14 & 273 & 327 & 27 & 50 & 18 & 3 weeks & [53] \\
\hline H. cupressiforme & n.d. & n.d. & 14.7 & 2.11 & 31.5 & 43.3 & 13.6 & 19.7 & n.d. & 4 weeks & [41] \\
\hline H. cupressiforme & n.d. & 2.28 & 35.4 & $<\mathrm{DL}$ & 29.9 & 17.6 & 11.6 & 1.19 & 5.07 & 6 weeks & [38] \\
\hline H.cupressiforme & $-1.7^{* *}$ & $-2.9 * *$ & 16 & 0.3 & 25.6 & 29.9 & 11.7 & 3.7 & 2.8 & 6 weeks & [43] \\
\hline H.cupressiforme & 10 & 26 & 367 & 9.34 & 309 & 232 & 57 & 12 & 17 & 6 weeks & [39] \\
\hline P. purum & n.d. & 15.1 & 60.6 & 6.06 & 57.6 & 208 & 14.5 & 5.30 & n.d & 8 weeks & [54] \\
\hline S. girgensohnii & 10.4 & 14.6 & 90.4 & 10.2 & 206 & 175.9 & 181.5 & 42.3 & 92.4 & 8 weeks & [55] \\
\hline
\end{tabular}

${ }^{*}$ When more than one study site appeared in a given publication shown in Table 2, the study site where PAHs content in mosses was highest, or where their labeled amount was highest, was selected for comparison; n.d.—no data; $<\mathrm{DL}$ and $<10.0$ - below the detection limit.

** Post-minus, pre-exposure difference is shown; therefore, negative numbers are possible.

The examples from the literature, presented in Table 2, show the variation in the accumulation of PAHs by mosses at different times, places and during different exposure times. Our study presents PAHs increments after three months of exposure that ended in January, during the heating season. The significant increases in PAHs concentrations for the three moss species were influenced by the season of the study, as well as by the poor air quality in the area, which was previously reported [56-58]. Therefore, the time of study should be taken into account, as mosses show seasonality/periodicity of increased contamination depending on the study period [55,59]. Of the data presented, $P$. schreberi, which is also a passive bioindicator, demonstrated the highest concentration of adsorbed PAHs in our study [26,60]. The results of actual photochemical efficiency (yield) indicate that live mosses, when exposed to adverse conditions (environmental stress [61]), spend most of their exposure time in a physiological state (cryptobiosis) in which vital parameters are very low, but compounds are accumulated. Thus, it is not advisable to exclude measurements of viability during biomonitoring studies $[39,43]$. The influence of environmental factors has a significant impact on the life of plants (including mosses) [62] and the ways in which PAHs accumulate in a plant are also dependent on environmental conditions and the characteristics of the plant itself (how it is prepared for research) $[16,59,63]$.

It is essential for biomonitoring to be integrated with classical monitoring in order to demonstrate its applicability as a complementary method to routine instrumental measurements [48]. In one study, the concentrations of PAHs in mosses and active accumulators were correlated where the coefficient $\mathrm{r}$ of Pearson showed a significant correlation $\mathrm{R}=0.67$ [53]. It is not possible to replace instrumental monitoring with biomonitoring (see Figure 2), but the presented results indicate the possibility of using the moss bag technique as a method of supporting the classical instrumental monitoring of airborne PAHs in urban areas.

In food and environmental matrices, Benzo[a]pyrene (BEN(a)PYR) is probably the most studied PAH. However, in many cases, BEN(a)PYR represents only $1-20 \%$ of the total PAH concentration [61]. In 2002, the European Commission's Scientific Committee on Food (SCF) recommended that, in addition to BEN(a)PYR, other compounds in the PAH group should also be considered for the determination of carcinogenic effects [64]. The air pollution indicator for PAHs is the concentration of benzo(a)pyrene, which, according to Directive 2004/107/EC of the European Parliament and of the Council of 15 December 2004 (related to arsenic, cadmium, mercury, nickel and polycyclic aromatic hydrocarbons in ambient air) should not exceed $1 \mathrm{ng} / \mathrm{m}^{3}$ [65]. In mosses, the concentration of BEN(a)PYR was below the limit of quantification of the analytical method used, but it should be remembered that living mosses will only accumulate bioavailable forms of analytes. At the same time, high concentrations of other mutagenic PAHs were found both in TSP and 
in the living biomonitor (in samples of three moss species). Analyzing the data from the work of Sapota [66] and comparing them with the test results obtained herein, PAHs with high relative carcinogenicity and mutagenicity were determined in mosses, e.g., 0.62 for benzo(a)anthracene and 0.37 for chrysene.

\section{Materials and Methods}

The species used for this study were the mosses P. schreberi, S. fallax and D. polysetum, which are used in biomonitoring studies [67-69], including PAH contamination [51]. They were collected in October 2020 from forests in the Swietokrzyskie Voivodship in southeastern Poland, which can be considered a clean background site. Mosses were collected at least $5 \mathrm{~m}$ away from the canopy of the trees, so as to not be directly exposed to precipitation (only the green parts of mosses were taken) [70].

Moss samples were taken and prepared before exposure according to a pre-developed methodology [71]. Next, $2 \mathrm{~g}$ of mosses were each packed into nylon nets and exposed in bags. The control sample was not exposed and was left for pre-exposure analyses of PAHs concentrations to assess background pollution. Moss samples were suspended on the viewing terrace of one Opole University buildings (Opole, Poland). The mosses were exposed for 3 months during the winter season (27 October 2020-27 January 2021). Nine bags were removed for each month of exposure ( 3 bags for each species). At the same time, total suspended particles were collected on QM-A quartz filters (Whatman, $47 \mathrm{~mm}$ diameter). The sampling time was $24 \mathrm{~h}$. Airflow in PNS3D15/LVS3D dust collector was measured as $2.3 \mathrm{~m}^{3} / \mathrm{h}$ following the standard procedure [72].

One gram of each sample was extracted with $10 \mathrm{~mL}$ of methanol (HPLC grade) using lab shaker GFL 3006. All samples were extracted for $24 \mathrm{~h}$. The eluate obtained was subjected to gas chromatographic analysis, which was carried out using a Thermo Trace 1310 a gas chromatograph equipped with a triple quadrupole MS detector Thermo TSQTM 8000 Evo, an autosampler CTC Analytics AG, PAL LHX-xt and a programmed temperature vaporizing injector. Analytical column SCION $5 \mathrm{~ms}(30 \mathrm{~m} \times 0.25 \mathrm{~mm} \times 0.25 \mu \mathrm{m})$ was used. The temperature programme of the chromatographic oven started at $70{ }^{\circ} \mathrm{C}$, graduated, at first, by $15^{\circ} \mathrm{C}$ per min to $200{ }^{\circ} \mathrm{C}$ and was maintained for $5 \mathrm{~min}$, followed by a temperature gradient of $8^{\circ} \mathrm{C}$ per min to final temperature of $320^{\circ} \mathrm{C}$, which was maintained for $5 \mathrm{~min}$. The carrier gas (helium 5.0) flow was adjusted to $2 \mathrm{~mL}$ per min.

Calibration with internal standard was performed for the determination of all PAH. Four deuterated standards: naphthalene $-\mathrm{d} 8$, phenanthrene $-\mathrm{d} 10$, chrysene $-\mathrm{d} 12$ and perylene-d12, and mixed-standard Dr. Ehrenstorfer PAH-Mix 9, were used for determination of PAH. Limits of quantification were $1 \mu \mathrm{g} \cdot \mathrm{mL}^{-1}$ for each of the analytes. Regarding the analytical methods, a detailed description of individual PAHs MS parameters is provided in the Supplementary Material.

Chlorophyll fluorescence of photosystem II, actual photochemical efficiency (yield) was measured using the modulated portable fluorometer (Opti-Sciences, Hudson, NH, USA) under ambient light conditions [73].

The Lilliefors modifications of the Kolmogorov-Smirnov test failed to prove a hypothesis about data normality [74]. Therefore, differences between moss species, in terms of the concentration of PAHs that they contained, were evaluated by the Wilcoxon test [75].

\section{Conclusions}

The results of the biomonitoring study demonstrate the applicability of the moss bag technique to determine selected PAHs. In the active biomonitoring of air pollution by these compounds, the so-far rarely used species, P. schreberi, and two others, S. fallax and D. polysetum, were chosen. The increments in PAH concentrations in the mosses indicate that the former proved to be the best biomonitoring species. This species was also most suitable from the perspective of areal abundance, which qualified it for the mapping purposes. Biological monitoring showed an accumulation of PAHs at a specific time, e.g., winter and heating seasons, which is confirmed by accumulated concentrations 
by mosses, as well as those deposited in TSP on the filter, where an additional 4 PAHs compounds were found. The viability of the mosses decreased to low values during the exposure, which shows the state of moss cryptobiosis as a physiological state serving their survival in unfavorable environmental conditions, which included air pollution with PAHs. The correlation between PAH in mosses and in TSP on the filter indicates that the use of environmental samples can support classical monitoring in urban areas. Further research should focus on the optimization and standardization of the moss bag technique in PAH monitoring.

Supplementary Materials: The following are available online, Table S1: MS parameters of PAH determination method.

Author Contributions: Conceptualization, P.Ś. and M.R.; methodology, P.Ś., M.R., K.L. and V.A.; validation, P.H., S.W., K.L., V.A., M.R. and M.Z.-W.; formal analysis, P.Ś., P.H., S.W., K.L., V.A., M.R. and M.Z.-W.; investigation, P.Ś., P.H., S.W., K.L., V.A. and M.R.; writing—original draft preparation, P.Ś.; writing-review and editing, P.H., S.W., K.L., V.A., M.R. and M.Z.-W.; visualization, P.Ś.; supervision, M.R. and M.Z.-W.; project administration, P.H., S.W. and M.R.; funding acquisition, P.H. All authors have read and agreed to the published version of the manuscript.

Funding: The authors acknowledge the assistance provided by the Research Infrastructures NanoEnviCz (Project No. LM2018124) supported by the Ministry of Education, Youth and Sports of the Czech Republic. https://search.crossref.org/funding, accessed on 8 October 2021. Any errors may affect your future funding.

Institutional Review Board Statement: Not applicable.

Informed Consent Statement: Not applicable.

Data Availability Statement: The datasets used and/or analyzed during the current study are available from the corresponding author on reasonable request.

Acknowledgments: We would like to thank the invaluable help and support of Piotr Iwasiewicz, Director of ATMOSERVICE Sp. z o.o. in Poznań, for lending a PNS3D15/LVS3D dust collector for the study and thank him for his contribution.

Conflicts of Interest: The authors declare no conflict of interest. The funders had no role in the design of the study; in the collection, analyses, or interpretation of data; in the writing of the manuscript, or in the decision to publish the results.

Sample Availability: Samples of the compounds are available from the authors.

\section{References}

1. Zhang, X.; Yang, L.; Zhang, H.; Xing, W.; Wang, Y.; Bai, P.; Zhang, L.; Hayakawa, K.; Toriba, A.; Wei, Y.; et al. Assessing approaches of human inhalation exposure to polycyclic aromatic hydrocarbons: A review. Int. J. Environ. Res. Public Health 2021, $18,3124$. [CrossRef]

2. Scherer, G.; Frank, S.; Riedel, K.; Meger-Kossien, I.; Renner, T. Biomonitoring of Exposure to Polycyclic Aromatic Hydrocarbons of Nonoccupationally Exposed Persons. Cancer Epidemiol. Biomarkers Prev. 2000, 9, 373-380.

3. Thai, P.K.; Li, Z.; Sjödin, A.; Fox, A.; Diep, N.B.; Binh, T.T.; Mueller, J.F. Biomonitoring of polycyclic aromatic hydrocarbons exposure in small groups of residents in Brisbane, Australia and Hanoi, Vietnam, and those travelling between the two cities. Chemosphere 2015, 139, 358-364. [CrossRef]

4. Hassan, S.K. Particle-bound polycyclic aromatic hydrocarbon in the atmosphere of heavy traffic areas in Greater Cairo, Egypt: Status, Source, and Human Health Risk Assessment. Atmosphere 2018, 9, 368. [CrossRef]

5. Kwak, K.H.; Woo, S.H.; Kim, K.H.; Lee, S.B.; Bae, G.N.; Ma, Y., II; Sunwoo, Y.; Baik, J.J. On-road air quality associated with traffic composition and street-canyon ventilation: Mobile monitoring and CFD modeling. Atmosphere 2018, 9, 92. [CrossRef]

6. Lhotka, R.; Pokorná, P.; Zíková, N. Long-term trends in PAH concentrations and sources at rural background site in Central Europe. Atmosphere 2019, 10, 687. [CrossRef]

7. Mikel, D.K.; Aneja, V.P. Measurements and analysis of polycyclic aromatic hydrocarbons near a major interstate. Atmosphere 2016, 7, 131. [CrossRef]

8. Choi, H.; Harrison, R.; Komulainen, H.; Saborit, J.M.D. Polycyclic aromatic hydrocarbons. In WHO Guidelines for Indoor Air Quality: Selected Pollutants; World Health Organization: Geneva, Switzerland, 2010; pp. 289-346, ISBN 9789289002134.

9. Trojanowska, M.; Świetlik, R. Cancer risk assessment resulting from respiratory tracts exposure to benzo(a)pyrene in selected Polish cities. Environ. Med. 2013, 16, 14-22. (In Polish) 
10. 1AL-Alam, J.; Chbani, A.; Faljoun, Z.; Millet, M. The use of vegetation, bees, and snails as important tools for the biomonitoring of atmospheric pollution-A review. Environ. Sci. Pollut. Res. 2019, 26, 9391-9408. [CrossRef] [PubMed]

11. Mukhopadhyay, S.; Dutta, R.; Das, P. A critical review on plant biomonitors for determination of polycyclic aromatic hydrocarbons (PAHs) in air through solvent extraction techniques. Chemosphere 2020, 251, 126441. [CrossRef]

12. Glad, M.; Bihari, N.; Jakšić, Ž.; Fafanđel, M. Comparison between resident and caged mussels: Polycyclic aromatic hydrocarbon accumulation and biological response. Mar. Environ. Res. 2017, 129, 195-206. [CrossRef] [PubMed]

13. Vaezzadeh, V.; Zakaria, M.P.; Bong, C.W.; Masood, N.; Mohsen Magam, S.; Alkhadher, S. Mangrove Oyster (Crassostrea belcheri) as a Biomonitor Species for Bioavailability of Polycyclic Aromatic Hydrocarbons (PAHs) from Sediment of the West Coast of Peninsular Malaysia. Polycycl. Aromat. Compd. 2019, 39, 470-485. [CrossRef]

14. Rybak, J.; Olejniczak, T. Accumulation of polycyclic aromatic hydrocarbons (PAHs) on the spider webs in the vicinity of road traffic emissions. Environ. Sci. Pollut. Res. 2014, 21, 2313-2324. [CrossRef]

15. Rutkowski, R.; Rybak, J.; Rogula-Kozłowska, W.; Bełcik, M.; Piekarska, K.; Jureczko, I. Mutagenicity of indoor air pollutants adsorbed on spider webs. Ecotoxicol. Environ. Saf. 2019, 171, 549-557. [CrossRef]

16. Harmens, H.; Foan, L.; Simon, V.; Mills, G. Terrestrial mosses as biomonitors of atmospheric POPs pollution: A review. Environ. Pollut. 2013, 173, 245-254. [CrossRef]

17. Augusto, S.; Máguas, C.; Branquinho, C. Guidelines for biomonitoring persistent organic pollutants (POPs), usinglichens and aquatic mosses-A review. Environ. Pollut. 2013, 180, 330-338. [CrossRef] [PubMed]

18. Huang, S.; Dai, C.; Zhou, Y.; Peng, H.; Yi, K.; Qin, P.; Luo, S.; Zhang, X. Comparisons of three plant species in accumulating polycyclic aromatic hydrocarbons (PAHs) from the atmosphere: A review. Environ. Sci. Pollut. Res. 2018, 25, 16548-16566. [CrossRef]

19. Carlberg, G.E.; Ofstad, E.B.; Drangsholt, H.; Steinnes, E. Atmospheric deposition of organic micropollutants in Norway studied by means of moss and lichen analysis. Chemosphere 1983, 12, 341-356. [CrossRef]

20. Knulst, J.C.; Westling, H.O.; Brorstriom-Lunden, E. Airborne Organic Micropollutant Concentrations in Mosses and Humus as Indicators for Local Versus Long-Range Sources. Environ. Monit. Assess. 1995, 36, 75-91. [CrossRef]

21. Foan, L.; Sablayrolles, C.; Elustondo, D.; Lasheras, E.; González, L.; Ederra, A.; Simon, V.; Santamaría, J.M. Reconstructing historical trends of polycyclic aromatic hydrocarbon deposition in a remote area of Spain using herbarium moss material. Atmos. Environ. 2010, 44, 3207-3214. [CrossRef]

22. Martinez-Swatson, K.; Mihály, E.; Lange, C.; Ernst, M.; Dela Cruz, M.; Price, M.J.; Mikkelsen, T.N.; Christensen, J.H.; Lundholm, N.; Rønsted, N. Biomonitoring of Polycyclic Aromatic Hydrocarbon Deposition in Greenland Using Historical Moss Herbarium Specimens Shows a Decrease in Pollution During the 20th Century. Front. Plant Sci. 2020, 11, 1085. [CrossRef]

23. Foan, L.; Leblond, S.; Thöni, L.; Raynaud, C.; Santamaría, J.M.; Sebilo, M.; Simon, V. Spatial distribution of PAH concentrations and stable isotope signatures $(\delta 13 \mathrm{C}, \delta 15 \mathrm{~N})$ in mosses from three European areas-Characterization by multivariate analysis. Environ. Pollut. 2014, 184, 113-122. [CrossRef]

24. Dreyer, A.; Nickel, S.; Schröder, W. (Persistent) Organic pollutants in Germany: Results from a pilot study within the 2015 moss survey. Environ. Sci. Eur. 2018, 30, 1-14. [CrossRef]

25. Oishi, Y. Comparison of moss and pine needles as bioindicators of transboundary polycyclic aromatic hydrocarbon pollution in central Japan. Environ. Pollut. 2018, 330-338. [CrossRef]

26. Yakovleva, E.; Gabov, D. Polyarenes accumulation in tundra ecosystem influenced by coal industry of Vorkuta. Polish Polar Res. 2020, 41, 237-268.

27. Yakovleva, E.V.; Gabov, D.N.; Kondratenok, B.M.; Dubrovskiy, Y.A. Two-Year Monitoring of PAH in the Soils and Pleurozium schreberi under the Impact of Coal Mining. Polycycl. Aromat. Compd. 2021, 41, 2055-2070. [CrossRef]

28. Godzik, B.; Szarek-Łukaszewska, G.; Kapusta, P.; Stępień, K. PAHs concentrations in Poland using moss Pleurozium schreberi as bioindicator. Polish Bot. J. 2014, 59, 137-144. [CrossRef]

29. Dolegowska, S.; Migaszewski, Z.M. PAH concentrations in the moss species Hylocomium splendens (Hedw.) B.S.G. and Pleurozium schreberi (Brid.) Mitt. from the Kielce area (south-central Poland). Ecotoxicol. Environ. Saf. 2011, 74, 1636-1644. [CrossRef]

30. Wegener, J.W.M.; van Schaik, M.J.M.; Aiking, H. Active biomonitoring of polycyclic aromatic hydrocarbons by means of mosses. Environ. Pollut. 1992, 76, 15-18. [CrossRef]

31. Viskari, E.L.; Rekilä, R.; Roy, S.; Lehto, O.; Ruuskanen, J.; Kärenlampi, L. Airborne pollutants along a roadside: Assessment using snow analyses and moss bags. Environ. Pollut. 1997, 97, 153-160. [CrossRef]

32. Orliński, R. Multipoint moss passive samplers assessment of urban airborne polycyclic aromatic hydrocarbons: Concentrations profile and distribution along Warsaw main streets. Chemosphere 2002, 48, 181-186. [CrossRef]

33. Ares, A.; Aboal, J.R.; Carballeira, A.; Giordano, S.; Adamo, P.; Fernández, J.A. Moss bag biomonitoring: A methodological review. Sci. Total Environ. 2012, 432, 143-158. [CrossRef]

34. Foan, L.; Simon, V. Optimization of pressurized liquid extraction using a multivariate chemometric approach and comparison of solid-phase extraction cleanup steps for the determination of polycyclic aromatic hydrocarbons in mosses. J. Chromatogr. A 2012, 1256, 22-31. [CrossRef] [PubMed] 
35. Concha-Graña, E.; Muniategui-Lorenzo, S.; De Nicola, F.; Aboal, J.R.; Rey-Asensio, A.I.; Giordano, S.; Reski, R.; López-Mahía, P.; Prada-Rodríguez, D. Matrix solid phase dispersion method for determination of polycyclic aromatic hydrocarbons in moss. J. Chromatogr. A 2015, 1406, 19-26. [CrossRef] [PubMed]

36. Aboal, J.R.; Concha-Graña, E.; De Nicola, F.; Muniategui-Lorenzo, S.; López-Mahía, P.; Giordano, S.; Capozzi, F.; Di Palma, A.; Reski, R.; Zechmeister, H.; et al. Testing a novel biotechnological passive sampler for monitoring atmospheric PAH pollution. J. Hazard. Mater. 2020, 381, 120949. [CrossRef]

37. Bustamante, J.; Liñero, O.; Arrizabalaga, I.; Carrero, J.A.; Arana, G.; Diego, A. De Sample pretreatment to differentiate between bioconcentration and atmospheric deposition of polycyclic aromatic hydrocarbons in mosses. Chemosphere 2015, 122, 295-300. [CrossRef]

38. Capozzi, F.; Di Palma, A.; Adamo, P.; Spagnuolo, V.; Giordano, S. Monitoring chronic and acute PAH atmospheric pollution using transplants of the moss Hypnum cupressiforme and Robinia pseudacacia leaves. Atmos. Environ. 2017, 150, 45-54. [CrossRef]

39. Capozzi, F.; Adamo, P.; Spagnuolo, V.; Giordano, S. Field comparison between moss and lichen PAHs uptake abilities based on deposition fluxes and diagnostic ratios. Ecol. Indic. 2021, 120, 106954. [CrossRef]

40. Vingiani, S.; De Nicola, F.; Purvis, W.O.; Concha-Graña, E.; Muniategui-Lorenzo, S.; López-Mahía, P.; Giordano, S.; Adamo, P. Active Biomonitoring of Heavy Metals and PAHs with Mosses and Lichens: A Case Study in the Cities of Naples and London. Water Air Soil Pollut. 2015, 226, 1-12. [CrossRef]

41. De Nicola, F.; Murena, F.; Costagliola, M.A.; Alfani, A.; Baldantoni, D.; Prati, M.V.; Sessa, L.; Spagnuolo, V.; Giordano, S. A multi-approach monitoring of particulate matter, metals and PAHs in an urban street canyon. Environ. Sci. Pollut. Res. 2013, 20, 4969-4979. [CrossRef]

42. Foan, L.; Domercq, M.; Bermejo, R.; Santamaría, J.M.; Simon, V. Mosses as an integrating tool for monitoring PAH atmospheric deposition: Comparison with total deposition and evaluation of bioconcentration factors. A year-long case-study. Chemosphere 2015, 119, 452-458. [CrossRef]

43. Capozzi, F.; Sorrentino, M.C.; Di Palma, A.; Mele, F.; Arena, C.; Adamo, P.; Spagnuolo, V.; Giordano, S. Implication of vitality, seasonality and specific leaf area on PAH uptake in moss and lichen transplanted in bags. Ecol. Indic. 2020, 108, 105727. [CrossRef]

44. Wang, Z.; Liu, S.; Bu, Z.J.; Wang, S. Degradation of polycyclic aromatic hydrocarbons (PAHs) during Sphagnum litters decay. Environ. Sci. Pollut. Res. 2018, 25, 18642-18650. [CrossRef]

45. Astel, A.; Astel, K.; Biziuk, M. PCA and multidimensional visualization techniques united to aid in the bioindication of elements from transplanted Sphagnum palustre moss exposed in the Gdańsk City Area. Environ. Sci. Pollut. Res. 2008, 15, 41-50. [CrossRef] [PubMed]

46. Kozielska, B.; Rogula-Kozłowska, W.; Klejnowski, K. Seasonal variations in health hazards from polycyclic aromatic hydrocarbons bound to submicrometer particles at three characteristic sites in the heavily polluted polish region. Atmosphere 2015, 6, 1-20. [CrossRef]

47. Godzik, B. Use of bioindication methods in national, regional and local monitoring in Poland-changes in the air pollution level over several decades. Atmosphere 2020, 11, 143. [CrossRef]

48. Vuković, G.; Aničić Uroševic, M.; Razumenić, I.; Kuzmanoski, M.; Pergal, M.; Škrivanj, S.; Popović, A. Air quality in urban parking garages (PM10, major and trace elements, PAHs): Instrumental measurements vs. active moss biomonitoring. Atmos. Environ. 2014, 85, 31-40. [CrossRef]

49. Ciesielczuk, T.; Olszowski, T.; Prokop, M.; Kłos, A. Application of mosses to identification of emission sources of polycyclic aromatic hydrocarbons. Ecol. Chem. Eng. S 2012, 19, 585-595.

50. Jóźwiak, M.A.; Rybiński, P. Assessment of air pollution along express roads and motorways of varied traffic load with the use of bioindicators. Rocz. Świętokrzyski Seria B Nauki Przyr. Kieleckie Tow. Nauk. 2013, 34, 51-63.

51. Rybinski, P.; Jozwiak, M. Bio-indicative assessment of motorway air pollution using thermal analysis. Polish J. Environ. Stud. 2014, $23,1617-1625$.

52. Zechmeister, H.G.; Dullinger, S.; Hohenwallner, D.; Riss, A.; Hanus-Illnar, A.; Scharf, S. Pilot study on road traffic emissions (PAHs, heavy metals) measured by using mosses in a tunnel experiment in Vienna, Austria. Environ. Sci. Pollut. Res. 2006, 13, 398-405. [CrossRef]

53. Skert, N.; Falomo, J.; Giorgini, L.; Acquavita, A.; Capriglia, L.; Grahonja, R.; Miani, N. Biological and artificial matrixes as pah accumulators: An experimental comparative study. Water Air Soil Pollut. 2010, 206, 95-103. [CrossRef]

54. Ares, Á.; Ángel Fernández, J.; Ramón Aboal, J.; Carballeira, A. Study of the air quality in industrial areas of Santa Cruz de Tenerife (Spain) by active biomonitoring with Pseudoscleropodium purum. Ecotoxicol. Environ. Saf. 2011, 74, 533-541. [CrossRef]

55. Vuković, G.; Urošević, M.A.; Pergal, M.; Janković, M.; Goryainova, Z.; Tomašević, M.; Popović, A. Residential heating contribution to level of air pollutants (PAHs, major, trace, and rare earth elements): A moss bag case study. Environ. Sci. Pollut. Res. 2015, 22, 18956-18966. [CrossRef]

56. Pochwała, S.; Gardecki, A.; Lewandowski, P.; Somogyi, V.; Anweiler, S. Developing of low-cost air pollution sensorMeasurements with the unmanned aerial vehicles in Poland. Sensors 2020, 20, 3582. [CrossRef]

57. Olszowski, T. Influence of individual household heating on PM2.5 concentration in a rural settlement. Atmosphere 2019, 10, 782. [CrossRef]

58. Svozilík, V.; Krakovská, A.S.; Bitta, J.; Jančík, P. Comparison of the air pollution mathematical model of pm10 and moss biomonitoring results in the Tritia region. Atmosphere 2021, 12, 656. [CrossRef] 
59. Sucharová, J.; Holá, M. PAH and PCB determination of the concentration gradient in moss Pleurozium schreberi near a highway, and seasonal variability at the background reference site. Int. J. Environ. Anal. Chem. 2014, 94, 712-727. [CrossRef]

60. Yakovleva, E.V.; Gabov, D.N.; Beznosikov, V.A.; Kondratenok, B.M.; Dubrovskiy, Y.A. Accumulation of PAHs in Tundra Plants and Soils under the Influence of Coal Mining. Polycycl. Aromat. Compd. 2017, 37, 203-218. [CrossRef]

61. Urošević, M.A.; Vuković, G.; Jovanović, P.; Vujičić, M.; Sabovljević, A.; Sabovljević, M.; Tomašević, M. Urban background of air pollution: Evaluation through moss bag biomonitoring of trace elements in Botanical garden. Urban For. Urban Green. 2017, 25, 1-10. [CrossRef]

62. Van Gaalen, K.E.; Flanagan, L.B.; Peddle, D.R. Photosynthesis, chlorophyll fluorescence and spectral reflectance in Sphagnum moss at varying water contents. Oecologia 2007, 153, 19-28. [CrossRef]

63. Giordano, S.; Sorbo, S.; Adamo, P.; Basile, A.; Spagnuolo, V.; Cobianchi, R.C. Biodiversity and Trace Element Content of Epiphytic Bryophytes in Urban andExtraurban Sites of Southern Italy. Plant Ecol. 2004, 170, 1-14. [CrossRef]

64. Plaza-Bolaños, P.; Frenich, A.G.; Vidal, J.L.M. Polycyclic aromatic hydrocarbons in food and beverages. Analytical methods and trends. J. Chromatogr. A 2010, 1217, 6303-6326. [CrossRef] [PubMed]

65. Official Journal of the European Union Directive 2004/107/EC of the European Parliament and of the Council of 15/12/2004 relating to arsenic, cadmium, mercury, nickel and polycyclic aromatic hydrocarbons in ambient air. Off. J. Eur. Union 2005, L23, 3-16.

66. Sapota, A. Polycyclic aromatic hydrocarbons (cyclohexane soluble tar substances). Documentation of proposed occupational exposure limit values (in Polish). Pod. Metod. Ocen. Środow. Przyr. 2002, 32, 179-208.

67. Zechmeister, H.G.; Rivera, M.; Köllensperger, G.; Marrugat, J.; Künzli, N. Indoor monitoring of heavy metals and NO2 using active monitoring by moss and Palmes diffusion tubes. Environ. Sci. Eur. 2020, 32, 1-12. [CrossRef]

68. Ryzhakova, N.K.; Rogova, N.S.; Borisenko, A.L. Research of Mosses Accumulation Properties Used for Assessment of Regional and Local Atmospheric Pollution. Environ. Res. Eng. Manag. 2014, 69, 84-91. [CrossRef]

69. Gorelova, S.V.; Frontasyeva, M.V.; Volkova, E.V.; Vergel, K.N.; Babicheva, D.E. Trace element accumulating ability of different moss species used to study atmospheric deposition of heavy metals in Central Russia: Tula region case study. Int. J. Biol. Biomed. Eng. 2016, 10, 271-285.

70. ICP Vegetation. Heavy Metals, Nitrogen and POPs in European Mosses: 2020 Survey. 2020. Available online: https: / / icpvegetation.ceh.ac.uk/sites/default/files/ICP\%20Vegetation\%20moss\%20monitoring\%20manual\%202020.pdf (accessed on 29 November 2021).

71. Świsłowski, P.; Kosior, G.; Rajfur, M. The influence of preparation methodology on the concentrations of heavy metals in Pleurozium schreberi moss samples prior to use in active biomonitoring studies. Environ. Sci. Pollut. Res. 2021, 28, 10068-10076. [CrossRef]

72. European Commission. EN 12341:2014 Ambient Air-Standard Gravimetric Measurement Method for the Determination of the PM10 or PM2,5 Mass Concentration of Suspended Particulate Matter; European Commission: Brussels, Belgium, 2014.

73. Šraj Kržič, N.; Gaberščik, A. Photochemical efficiency of amphibious plants in an intermittent lake. Aquat. Bot. 2005, 83, 281-288. [CrossRef]

74. Zar, J. Biostatistical Analysis, 5th ed.; Pearson: Upper Saddle River, NJ, USA, 2010; ISBN 9780131008465.

75. StatSoft Inc Statistica (Data Analysis Software System); Version 13; TIBCO Software Inc.: Tulsa, OK, USA, 2017. 